\title{
Huma Betang: Identitas Moral Kultural Suku Dayak Ngaju Kalimantan Tengah
}

\author{
Chris Apandie1, Endang Danial Ar² \\ 1Sekolah Tinggi Agama Kristen Negeri Palangka Raya, Indonesia \\ 2Prodi Pendidikan Kewarganegaraan Fakultas Ilmu Pengetahuan Sosial Universitas Pendidikan \\ Indonesia, Indonesia \\ ${ }^{1}$ capandie@gmail.com
}

\begin{abstract}
ABSTRAK
Dewasa ini benda cagar budaya seolah tidak lagi memiliki daya tarik filosofis dan tidak terpelihara, padahal benda cagar alam mengandung pemaknaan yang lebih dari sekedar fisik, bahkan merupakan identitas moral kultural. Eksplorasi nilai filosofis pada huma betang dapat menjadi langkah revitalisasi kebudayaan guna memperkuat identitas moral kultural warga negara Indonesia. Huma Betang dikenal secara luas dengan istilah "rumah besar". Rumah ini ditinggali orang Dayak sejak jaman dulu dengan beragam agama dan kepercayaan di dalamnya, namun penghuninya tetap hidup berdampingan. Penelitian ini menggunakan pendekatan kualitatif dengan metode etnografi. Lokasi penelitian adalah di Betang Toyoi Tumbang Malahoi Kecamatan Rungan Kabupaten Gunung Mas Kalimantan Tengah. Bagi masyarakat Suku Dayak huma betang tidak hanya sekedar tempat tinggal, tapi merupakan jantung dari struktur kehidupan orang Dayak. Identitas kultural yang terefleksi yaitu huma bentang: 1) sebagai refleksi kehidupan masyarakat yang toleran; 2) sebagai asal mula tumbuhnya rasa persatuan dan kebersamaan antar suku Dayak setelah kesepakatan damai Tumbang Anoi; 3) sebagai replika sistem komunal yang dianut masyarakat Suku Dayak; 4) mengandung pola kosmologi yang mencerminkan keseimbangan sebuah nilai; 5) sebagai cerminan kehidupan demokratis dan egaliter; 6) melalui pola kehidupan melahirkan konsep kepemimpinan Suku Dayak; 7) merepresentasikan prinsip kolektif; 8) sebagai model ideal sistem masyarakat pluralis.
\end{abstract}

Kata kunci: huma betang, identitas moral kultural, suku Dayak, Kalimantan Tengah

\begin{abstract}
Nowadays local and national cultures are gradually left behind. Cultural artifacts - while having beyond-physical meaning, even moral and cultural identities-are no longer maintained neither have philosophical attraction. Exploration of philosophical values in huma betang can be a step to revitalize culture in order to strengthen Indonesians' cultural moral identity. Huma Betang is commonly known as "the big house". Dayak people-a traditional ethnic group in Borneo - with diverse religions and beliefs have been inhabiting the houses for a long time in harmony and peace. This research used qualitative approach with ethnographic method. Research was located in Betang Toyoi Tumbang Malahoi, Rungan District, Gunung Mas Regency, Central Borneo province. For the Dayak people, huma betang is more than just a place to live; it is the center of Dayak's life structure. Cultural identities reflected are that huma bentang: 1) as a reflection of tolerance; 2) as the origin of unity and togetherness among Dayak people after the Tumbang Anoi peace agreement; 3) as a replica of communal system adopted by Dayak people; 4) contains cosmological patterns that reflect a balance of values; 5) as a reflection of democratic and egalitarian life; 6) through the pattern of life in it delivers the concept of Dayak's leadership; 7) represents the collective principle; 8) as the ideal model of a pluralist community system.
\end{abstract}


Keywords: huma betang, cultural morality identity, Dayak ethnic group, Central Kalimantan province

This work is licensed under the Creative Commons Attribution-ShareAlike 4.0 International License. (O2019 by the author(s).

Received: July $232019 \quad$ Revised: November $92019 \quad$ Accepted: November 202019

\section{PENDAHULUAN}

Indonesia dikenal sebagai negara yang memiliki corak budaya paling unik dan beragam. Indonesia merupakan negara majemuk terbesar di dunia dibuktikan oleh kenyataan sosiokultural maupun geografis yang begitu beragam dan luas. Secara geografis, Indonesia terdiri atas 17.508 pulau baik yang dihuni maupun tidak. Secara etnik, terdapat 1.128 suku bangsa. Keberagaman dan kekayaan budaya tersebut ditambah pula dari aspek bahasa, dimana terdapat tiga bahasa utama dengan 1211 bahasa dialek (Badan Pusat Statistik, 2018) Melalui semboyan Bhinneka Tunggal Ika, Indonesia paten dengan identitas pluralisme dan multikultralismenya. Ketua harian Komisi Nasional untuk United Nations Education, Scientific and Cutural Organization (UNESCO) mengatakan bahwa kekayaan suku dengan bahasa daerah dan pulau membuat Indonesia memiliki khasanah budaya yang beragam (Abdillah, 2011). Kekayaan budaya dan struktur geografis merupakan modal yang tidak dimiliki semua negara di dunia, dalam artian hanya beberapa negara saja yang memiliki keduanya. Maka dari itu UNESCO menggambarkan Indonesia sebagai negara yang kaya karena bisa mempertahankan Negara Kesatuan Republik Indonesia dan keutuhan bangsa padahal memiliki suku yang berbeda-beda.

Kenyataannya saat ini budaya Indonesia dirasa kian luntur. Masuknya budaya asing menjadi salah satu faktor mulai melunturnya kebudayaan daerah di Indonesia. Budaya sebagai identitas yang berarti ciri dan sifat khas yang melekat dapat dikatakan luntur bahkan mulai hilang. Hingga pada akhirnya Indonesia berujung pada krisis identitas dengan melunturnya budaya asli Indonesia. Dapat dilihat bahwa 10 karakter negatif terjadi dan mengemuka di negara ini, yakni: 1) meningkatnya kekerasan di kalangan remaja; 2) penggunaan bahasa yang buruk; 3) pengaruh peer group yang kuat dalam tindak kekerasan; 4) meningkatnya perilaku merusak diri (penggunaan narkoba, alkohol, dan seks bebas, serta bunuh diri); 5) semakin kaburnya pedoman moral baik dan buruk; 6) semakin menurunnya etos kerja; 7) semakin rendahnya rasa hormat kepada orang tua dan guru; 8) semakin rendahnya rasa tanggung jawab individu dan warganegara; 9) membudayaakan ketidakjujuran; 10) adanya rasa saling curiga dan kebencian antar sesama (Lickona, 2013).

Setidaknya, ada tiga hal yang menjadi akar krisis identitas budaya di Indonesia. Pertama adalah konsep identitas itu sendiri yang tidak pernah menjadi sesuatu yang absolut dan permanen. Berikutnya adalah kebijakan budaya terkait politik kebudayaan dari setiap rezim yang berkuasa di Indonesia. Sementara yang terakhir tentu saja akibat invasi kapitalisme global yang memberikan banyak sekali celah ambiguitas pada pengembangan dan pembentukan identitas budaya nasional (Sukarwo, 2017)

Berbicara mengenai hal-hal yang melatarbelakangi perlunya lagi kajian tentang nilai-nilai luhur yang ada pada sistem kebudayaan suatu daerah atau suku 
tertentu, kita kembali lagi pada keresahan tentang krisis identitas moral kultural yang ditandai dengan kecintaan para generasi muda terhadap budaya asing dibandingkan dengan identitas budayanya sendiri. Hal ini diperkuat oleh pemberitaan di media massa bahwa perilaku imitasi generasi muda saat ini yang lebih mengidolakan budaya luar menjadi salah satu faktor penyebab budaya lokal dan nasional telah perlahan-lahan ditinggalkan (Nainggolan, 2016).

Ironisnya ada kekhawatiran yang selalu mengemuka dan indikasi relasi keberagamaan yang saat ini terjadi di kota Palangka Raya saat ini dianggap dalam keadaan semu. Dialog Forum Komunikasi Umat Beragama Kota Palangka Raya dengan Rektor STAIN Palangka Raya pada 7 Juni 2013 lalu, mengafirmasi adanya potensi konflik keberagamaan yang laten terutama menyangkut relasi umat beragama. PMB No. 8 dan 9 tahun 2006, Pergub No. 1 tahun 2007 dan Perwal No. 8 tahun 2007 merupakan sederet regulasi yang menyulut polemik relasi antar umat beragama. Hasil dialog menyebutkan pemahaman sepatah terhadap peraturan tersebut kerap menimbulkan keresahan (Ade \& Affandi, 2016).

Kondisi bangsa Indonesia yang terpuruk melihat salah satu kasus nya yang ada di Kalimantan Tengah, William (2017) menyarankan Indonesia untuk kembali pada jati diri sebagai identitas bangsa dalam falsafah hidup yang menjunjung nilainilai dasar (basic values) sebagai bangsa yang besar dan bermoral. Untuk itu ada tiga langkah alternatif yang dapat dilakukan: pertama, memperbaharui sikap dasar dan perilaku anak bangsa yang terkait dengan nilai-nilai sosial, dan re-orientasi pada mentalitas kejujuran, keterbukaan, keadilan, dan kesetiakawanan. Kedua, Perbaikan reputasi bangsa dimulai dengan mewujudkan mentalitas kedisiplinan scara nasional, terutama dalam ketaatan, dan penegakan hukum yang adil kepada semua lapisan masyarakat, dengan sistem control yang serius sebagai kunci dalam penegakan nilai-nilai dasar kehidupan bangsa. Ketiga, membekali generasi muda dengan character building yang lebih sesuai cita-cita bangsa Indonesia.

Realitas yang terjadi menyadarkan pemerintah Indonesia termasuk warga negara agar dapat memperhatikan kelestarian budaya lokal yang mulai ditinggalkan. Pelestarian dan revitalisasi budaya nasional sebetulnya melibatkan seluruh pihak. Nilai moral dan ahlak adalah urusan mentalitas dan nampaknya memang menjadi salah satu problematika kehidupan bangsa yang penting di abad 21 ini. Maka dari itu perlu menjadi perhatian seluruh lapisan masyarakat, tidak hanya pemerintah saja. Era globalisasi yang terbuka, terpaan informasi sangat memungkinkan seseorang mengadopsi nilai-nilai, pengetahuan, dan kebiasaan luar lingkungan sosialnya dan jauh dari jangkauannya secara fisik (Sardjiyo, 2011). Lebih dari itu nilai-nilai yang diikuti kebanyakan tidak sesuai dengan kultur ketimurannya, akar budaya dan norma agamanya.

Salah satu upaya yang dilakukan pemerintah pusat maupun daerah dalam rangka mensukseskan pewarisan nilai budaya yang diharapkan ialah dengan merevitalisasi kebudayaan lokal sebagai landasan kebudayaan nasional. Tujuannya tentu adalah menggali kembali budaya-budaya lokal yang pernah populer dan diketahui secara luas oleh masyarakat. Dengan demikian revitalisasi kebudayaan dapat dimulai dari kearifan budaya lokal daerah salah satunya adalah eksplorasi falsafah kebudayaan lokal seperti huma betang. 
Filosofi huma betang ini berangkat dari pemahaman mengenai tujuh unsur kebudayaan (cultural universal) yaitu: (1) Sistem religi yang terdiri dari sistem kepercayaan, sistem nilai dan pandangan hidup, komunikasi keagamaan, upacara keagamaan; (2) Sistem kemasyarakatan atau organisasi sosial terdiri dari kekerabatan, asosiasi dan perkumpulan, sistem kenegaraan, sistem kesatuan hidup, perkumpulan; (3) Sistem pengetahuan terdiri dari flora dan fauna, waktu, ruang dan bilangan, tubuh manusia dan perilaku antar sesama manusia; (4) Bahasa terdiri dari alat untuk berkomunikasi berbentuk lisan dan tulisan; (5) Kesenian yang terdiri dari seni patung/pahat, relief, lukis dan gambar, rias, vokal, musik, bangunan, kesusastraan, drama; (6) Sistem mata pencaharian hidup atau sistem ekonomi terdiri dari kegiatan berburu dan mengumpulkan makanan, bercocok tanam, peternakan, perikanan, perdagangan; (7) Sistem peralatan hidup atau teknologi terdiri dari sistem produksi, distribusi, transportasi, peralatan komunikasi, peralatan konsumsi dalam bentuk wadah, pakaian dan perhiasan, tempat berlindung dan perumahan, dan senjata (Koentjaraningrat, 1993).

Rumah adat masuk ke dalam dua unsur kebudayaan sekaligus, yaitu bangunan dalam unsur kesenian dan tempat berlindung dalam unsur sistem peralatan hidup atau teknologi. Pemahaman tentang unsur kebudayaan ini menunjukkan identitas, yang mana berarti dalam karya budaya tidak lain adalah karya manusia itu sendiri. Khusus mengenai rumah adat yang merupakan bahasan unsur budaya fisik, hal ini tidak lepas dari filosofi dan nilai-nilai kebudayaan yang kental. Maka dari itu rumah adat dapat dijadikan salah satu titik tolak revitalisasi kebudayaan yang dimaksudkan.

Huma Betang adalah rumah adat masyarakat Kalimantan Tengah. "Rumah yang dibangun dengan cara gotong royong ini berukuran besar dan panjang mencapai 30-150 meter, lebarnya antara 10-30 meter, bertiang tinggi antara 3-4 meter dari tanah" (T. Riwut, 2003). Penghuni Huma Betang bisa mencapai seratus bahkan dua ratus jiwa yang merupakan satu keluarga besar dan dipimpin oleh seorang bakas lewu atau Kepala Suku. Kalimantan Tengah memiliki budaya yang sangat beragam mulai dari agama, suku dan bahasa, walaupun demikian masyarakat Dayak penduduk asli Kalimantan Tengah tetap menjaga persatuan agar perbedaan yang ada tidak menjadi masalah bagi mereka. Sikap toleransi antar umat beragama mejadi salah satu contoh bagaimana warga Kalimantan Tengah menjaga kerukunan diantaranya. Hal inilah yang dianggap menjadi filosofi dari huma betang itu sendiri.

\section{Gambar 1. Betang Toyoi}
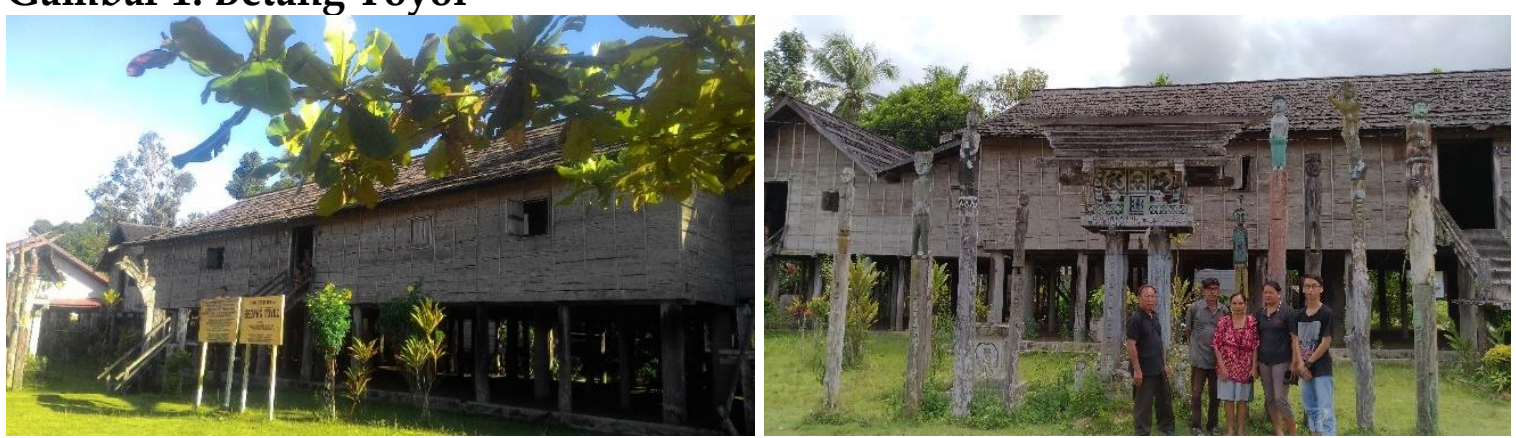

Sumber: Dokumentasi Peneliti (2017) 
Huma Betang dikenal secara luas dengan istilah "rumah besar". Rumah ini ditinggali oleh banyak orang dengan beragam agama dan kepercayaan, namun tetap hidup berdampingan. Rukun dan saling menghormati ritual ibadah agama masingmasing. Praktik kehidupan yang damai dan harmonis membuat Huma Betang adalah sebuah simbol dan filosofis kehidupan masyarakat di Kalimantan Tengah (Kalteng) seperti yang terlihat di Kota Palangka Raya, Ibukota Provinsi Kalteng. "Melalui konsep huma betang itu pula berbagai program pembangunan di wilayah ini diterapkan, artinya masyarakat diajak secara toleran dan bahu membahu membangun wilayah" (Zainuddin, 2012). Huma betang menjadi inti dari perilaku hidup orang Dayak yang toleran, sehingga dapat dikatakan menjadi jantung kebudayaan suku Dayak secara keseluruhan, termasuk suku Dayak Ngaju. Sistem nilai yang tercermin dalam huma betang menjadi pola pikir dan kecenderungan perilaku orang Dayak.

Berkaitan dengan hal ini, revitalisasi kebudayaan sekaligus pengembangan karakter dalam bentuk identitas moral kultural melalui kearifan budaya lokal tentu sangat diperlukan. Karakter yang terbentuk dan menjadi identitas dapat ditemukan dari pengembangan system nilai kebudayaan yang ada pada cagar budaya, misalnya huma betang. Transformasi nilai budaya yang dianggap kuno menjadi pola karakter yang kontekstual dengan realitas saat ini diperlukan sebagai pendekatan yang efektif bagi generasi muda, karena alasan; -alasan filosofis, ideologis, historis dan sosiokultural (Pemerintah Republik Indonesia, 2010).

Lunturnya kebudayaan nasional menjadi titik tolak pemikiran perlunya revitalisasi budaya nasional. Salah satu unsur kebudayaan yang hampir punah adalah eksistensi huma betang di wilayah masyarakat Dayak Kalimantan Tengah. Revitalisasi budaya dapat dimulai dari pengangkatan nilai-nilai kearifan lokal sebagai identitas moral kultural yang tumbuh dari masyarakat, salah satunya dari filosofi rumah adat (huma betang). Nilai-nilai luhur pada dasarnya perlu diwariskan dari generasi ke generasi. Hal ini dilakukan sebagai upaya pemeliharaan budaya dan sebagai bentuk upaya pertahanan terhadap terpaan budaya asing dengan budaya lokal daerah sebagai penangkalnya.

Berdasarkan latar belakang penelitian yang telah dikemukakan di atas, rumusan masalah dalam kajian ini adalah "bagaimana huma betang diimplementasikan sebagai identitas moral kultural Suku Dayak Ngaju di Kalimantan Tengah?". Dengan demikian tujuan dari diadakan penelitian ini adalah mensintesis kajian tentang huma betang sebagai identitas moral kultural Suku Dayak Ngaju di Kalimantan Tengah.

\section{METODE PENELITIAN}

Pendekatan yang digunakan dalam penelitian ini merupakan pendekatan kualitatif. Peneliti memiliki alasan bahwa dengan corak pendekatan penelitian kualitatif yang alamiah, maka situasinya akan benar-benar bertumpu pada apa yang nyata dan sesuai fakta. Terlebih lagi penelitian budaya benar-benar memerlukan observasi alamiah yang terus menerus dan berkelanjutan.

Kemudian nilai norma serta interaksi simbolik yang telah diamati perlu diterjemahkan dan diinterpretasikan bersamaan dengan teori pendukung yang telah 
ditentukan. Maka dari itu perlu menggunakan pendekatan kualitatif yang bersifat penelitian interpretative dan mendalam ketika mengkaji sesuatu hal. Melebihi data angka dan menghindari penyajian permukaan penelitian nya saja. Menurut Raco (2010), penelitian kualitatif merupakan penelitian yang cocok mendalami lingkungan, pengalaman, keadaan faktual, situasi sosial, politik, ekonomi, budaya yang berlaku di suatu tempat pada suatu waktu.

Melalui pendekatan yang digunakan, peneliti hendak mengumpulkan data mengenai kondisi kebudayaan yaitu falsafah huma betang, dengan beberapa komponen yang diamati dalam penelitian, yaitu interaksi antar warga masyarakat penghuni betang dan penduduk sekitar betang, situasi keseharian penghuni dan masyarakat sekitar, dan kondisi alamiah huma betang itu sendiri.

Metode yang dipilih dalam penelitian ini ialah metode etnografi. Adapun tata cara yang ditempuh peneliti secara garis besar terbagi ke dalam dua tahap, yakni tahap awal sebagai tahap penjajakan, studi pendahuluan, serta dilakukannya pencarian sumber sebanyak-banyaknya guna pertimbangan pemilihan narasumber dan lokasi penelitian betang yang tepat. Kemudian tahap selanjutnya dilakukannya pengumpulan data diikuti catatan etnografer yang berkelanjutan sejak penulis mengumpulkan bahan proposal mengenai huma betang.

Penelitian dan pendalaman yang dilakukan peneliti selama kurang lebih satu setengah bulan di lapangan. Aktivitas ini meliputi kegiatan penulisan deskripsi kondisi dan sejarah huma betang secara detil; pendalaman informasi yang didapat sebelumnya dengan cara informal kepada narasumber; penjelajahan situasi serta komunikasi penghuni betang serta penduduk sekitar, terutama berkaitan dengan tema-tema kultural dan nilai keadaban; memaparkan kehidupan sehari-hari yang dilakukan secara rutin; Menganalisis serta menginterpretasi ulang data guna memperkuat data penelitian dengan mengkonfirmasi kepada narasumber.

Istilah Etnografi sendiri berasal dari kata ethno (bangsa) dan graphy (menguraikan), sehingga etnografi menggambarkan suatu budaya dan cara lain dalam memahami cara hidup dari sudut pandang asli (Neuman, 2003). Kajian etnografi biasanya memuat konteks kehidupan yang menyeluruh namun memusatkan pada kebudayaan dan identitas. Adapun pengertian secara spesifik, "etnografi adalah pendekatan empiris dan teoretis yang bertujuan mendapatkan deskripsi dan analisis mendalam tentang kebudayaan berdasarkan penelitian lapangan yang intensif" (Nurhadi, 2006).

Lokasi penelitian adalah di Betang Toyoi Tumbang Malahoi Kecamatan Rungan Kabupaten Gunung Mas Kalimantan Tengah. Lokasi ini dipilih karena sejauh pengamatan peneliti, rumah betang inilah yang sampai saat ini masih berdiri dan dihuni masyarakat Dayak. Teknik pengumpulan daya yang dipilih ialah catatan etnografer, observasi, dan wawancara. Sumber data dan jenis data yang terdiri atas kata-kata dan tindakan, sumber tertulis, foto.

Analisis data yang dilakukan terdiri dari reduksi data, sajian data, display data, kesimpulan, dan verifikasi. Pengolahan data dimulai dari menelaah seluruh data yang tersedia dari wawancara, pengamatan, dokumen pribadi, dokumen resmi, gambar, foto, dan sebagainya. Setelah itu mengadakan reduksi data yang dilakukan dalam bentuk rangkuman inti, proses dan pernyataan-pernyataan yang perlu 
dicantumkan dan tidak. Kemudian menyusunnya dalam satuan-satuan. Satuansatuan itu diklasifikasi untuk kemudian diadakan pemeriksaan keabsahan data.

\section{HASIL DAN PEMBAHASAN}

\section{Falsafah Huma Betang}

Kebudayaan dapat dikatakan sebagai pola dari simbol-simbol dan makna yang terjalin serta diwariskan dari generasi ke generasi. Berbicara mengenai kebudayaan berarti kita berbicara tentang budi dan akal, sebagaimana pengertian kebudayaan menurut Koentjaraningrat (1993) bahwa "budaya merupakan gagasan karya manusia yang harus dibiasakannya dengan belajar, beserta keseluruhan dari hasil budi dan karyanya itu". Bertolak pada pengertian tersebut, budaya perlu dibiasakan karena berbentuk pola tingkah laku yang bermakna. Kebudayaan mengandung nilai-nilai yang dijadikan pandangan hidup sekelompok masyarakat, sebagaimana pengertian pandangan hidup yang berarti "nilai-nilai yang dianut oleh suatu masyarakat dengan dipilih secara selektif oleh individu, kelompok, atau bangsa" (Setiadi, 2006). Nilai-nilai yang terkandung dalam pandangan hidup juga merepresentasikan tingkah laku manusia yang tidak bisa dipisahkan dari konteks kebudayaan, sebab kebudayaan pada hakikatnya mengandung nilai. Nilai yang terkandung dalam kebudayaan secara langsung mempengaruhi dan dipengaruhi oleh dinamika kehidupan manusia.

Berhubungan dengan hal ini, pengembangan identitas moral kultural melalui kearifan budaya lokal tentu sangat diperlukan. Sebab sebagaimana dikatakan dalam Desain Induk Pembangunan Karakter Bangsa Tahun 2010-2025 (2010), secara sosio kultural pembangunan karakter bangsa merupakan suatu keharusan bagi bangsa yang multikultural. Disamping itu pembangunan karakter dari aspek sosio kultural berkaitan pula dengan nilai dan norma serta moral dalam kehidupan manusia, yang mana menurut Tugiman (2012) "norma-norma moral adalah tolak ukur untuk menentukan betul salahnya sikap dan tindakan manusia dilihat dari segi baik buruknya sebagai manusia". Dalam adat istiadat (sistem budaya) terdapat juga sistem norma dan moralitas. Disitulah salah satu fungsi sistem budaya adalah menata serta menetapkan tindakan-tindakan dan tingkah laku manusia dalam skema komponen-komponen pranata social (Koentjaraningrat, 1993).

Sebagaimana temuan penelitian Dinas Kebudayaan dan Pariwisata Kabupaten Gunung Mas, Bapak Sewantana Puja, menguraikan sejarah berdirinya huma betang di Kalimantan Tengah. Beliau mengatakan bahwa huma betang di Kalimantan Tengah itu tidak hanya sebagai tempat tinggal saja, keberadaannya adalah refleksi yang tidak pernah pudar sampai hari ini. Sejak dulu ditinggali nenek moyang Suku Dayak penuh dengan filosofi, bukan sekedar bangunan panjang. Sebagaimana pengertian filosofi atau falsafah (Depdiknas, 2018) yang berarti "sikap batin dari suatu masyarakat atau dapat diartikan pula sebagai pandangan hidup", falsafah huma betang juga mengandung nilai-nilai yang dianut oleh masyarakat suku Dayak. Dapat dikatakan sebagai falsafah atau filsafat hidup, mengacu pula pada pengertian falsafah yang berarti "pandangan hidup masyarakat yang diyakini kebenarannya" (2009), huma betang mengandung nilai-nilai yang dianut oleh sekelompok masyarakat yaitu Suku Dayak dan telah menjadi pedoman atau 
pandangan hidup selama berabad-abad.

Huma betang melebihi bentuk fisik cagar budaya pada pandangan hidup Suku Dayak. Rumah adat tersebut sudah bertransformasi dari struktur pola hidup yang mengajarkan nilai-nilai moral. Dalam artian betang lebih dari sekedar tempat tinggal melepas Lelah setelah bekerja. "Huma betang for Dayak Ngaju more than just place to stay. Huma betang is center of social structure from the life of Dayak" (Laksono, 2006; Sangalang, Titi, \& Darjosanjoto, 2011). Huma betang menjadi replika kehidupan Suku Dayak dalam kehidupan nyata, atau dapat dikatakan sebagai ikon budaya Dayak yang mengandung nilai-nilai filosofi di dalamnya. Falsafah huma betang mengandung unsur moral, hukum adat, serta kemampuan dan kebiasaan lain yang diperoleh seorang anggota masyarakat dalam ruang lingkup Suku Dayak dan kearifan lokal yang ada di dalamnya (Haviland, 1985).

Pola perilaku dan cara-cara masyarakat Suku Dayak bertindak atau berkelakuan yang sama dinamakan struktur normatif disebut "design of living (garisgaris petunjuk dalam hidup)" (Soekanto, 2014). Artinya kebudayaan adalah suatu garis pokok tentang perilaku atau blueprint for behavior yang menetapkan peraturanperaturan mengenai apa yang seharusnya dilakukan, apa yang dilarang, dan sebagainya. Nilai-nilai kebudayaan yang ada pada falsafah huma betang juga menunjukkan sesuatu yang seharusnya dilakukan dan sesuatu yang dilarang mengacu pada sistem hukum adat Suku Dayak.

Huma betang sebagai rumah adat suku Dayak di Kalimantan Tengah sejak pertama didirikan pada jaman nenek moyang telah melambangkan pola hidup masyarakat suku Dayak. Pola pikir serta kebudayaan yang terjadi dalam masyarakat dan itu semua akan tergambar pada penataan ruang rumah tinggal mereka (Eviyanti, 2010). Raunagan luas di dalam huma betang meski sebagian besar tidak memiliki sekat namun memiliki fungsinya masing-masing sesuai dengan sistem adat yang dianut masyarakat Dayak (Langub, 2012).

Selajutnya filosofi masyarakat hidup suku Dayak yang menjadi refleksi dari huma betang adalah mekanisme menuju kerukunan yang terdiri dari; pertama, Hatamuei lingu nalatai, hapangaja karendem malempang, yang artinya bermusyawarah untuk mempersatukan pemikiran. Kedua, Hapungkal lingu nalatai, habangkalan karendem malempang, yang artinya bermufakat untuk mencapai kebulatan sehingga menjadi visi dan misi hal-hal yang mendasar. Ketiga, Hariak lingu nalatai haringkai karendem malempang, yang artinya bersama-sama menyebarluaskan visi, misi, dan kesepakatan hasil musyawarah dengan penuh rasa tanggung jawab.

Ketiga mekanisme di atas dirangkum menjadi prinsip hapungkal lingu nalatai hapangjan yang berarti bersatu dalam menyelesaikan masalah secara mufakat. Akan tetapi dibalik itu Kepala Desa Tumbang Malahoi, Tampung mengatakan bahwa nilai-nilai keadaban kewarganegaraan yang diimplementasikan pada keberadaan huma betang sudah mulai bergeser. Misalkan gotong royong yang pada jaman dahulu dilakukan ketika akan melaksanakan upacara kematian, warga berbondongbondong datang ke betang membawa berbagai macam bahan makanan untuk dimasak bersama-sama. Namun sekarang warga datang sebentar saja dan menyerahkan sejumlah uang sebagai tanda bantuan. Menurut kepala desa, hal ini merupakan pergeseran makna gotong royong dalam filosofi huma betang. 
Pergeseran nilai-nilai juga mempengaruhi kebiasaan (folkways) dan tata kelakuan (mores) (Horton \& Hunt, 1984). Maka dari itu nilai-nilai yang tercermin dari huma betang dapat menjadi suatu kebiasaan dan pada akhirnya menjadi identitas moral kultural yang melekat pada masyarakat Suku Dayak Ngaju hingga hari ini. Meskipun pada implementasinya terjadi restorasi maupun transformasi.

\section{Huma Betang sebagai Identitas Moral Kultural Suku Dayak}

Falsafah huma betang yang pada realitasnya telah sesuai dengan filosofi hidup suku Dayak sejak jaman dahulu, diamini Restyanto (2012) bahwa "betang sebagai rumah tinggal tradisional mesyarakat kalimantan, memiliki nilai startegis, sakral serta historis". Memiliki nilai penting terhadap perkembangan dan pertumbuhan kebudayaan dimasa yang akan datang.

Adapun kondisi huma betang yang kini tidak lagi ditinggali oleh seluruh keturunan pendiri betang (hanya beberapa keluarga saja), dikarenakan kondisi rumah yang tidak memungkinkan serta pola hidup yang mulai berubah. Hal ini sedikit banyak mengakibatkan nilai-nilai dalam falsafah huma betang tersebut sedikit berbeda pengimplementasiannya. Penghuni betang menegaskan bahwa meskipun masyarakat di luar betang menganggap nilai-nilai yang ada pada betang ini sudah mulai punah dan ditinggalkan, akan tetapi mereka tidak sedikitpun merasakan perubahan tersebut, karena mereka sendiri yang merasakan bersama seluruh keluarga yang ada pada silsilah betang.

Berdasarkan wawancara dengan Dinas Kebudayaan dan Pariwisata Kabupaten Gunung Mas, Bapak Sewantana Puja menyatakan bahwa betang merupakan simbol suku Dayak Kalimantan Tengah, yang mana falsafahnya atau filosofinya masih hidup hingga sekarang. Meski secara fisik sudah rusak, namun filosofi betang ini tetap melekat. Terlebih lagi pada jaman dahulu huma betang sempat menjadi lokasi tercetusnya perjanjian Tumbang Anoi. Perjanjian Tumbang Anoi yang dilakukan di Betang Tumbang Anoi pada 1894 adalah kesepakatan untuk mengakhiri pertikaian sesama suku Dayak yang ada di pulau Kalimantan. Perjanjian tersebut berisi kesepakatan untuk mengakhiri kebiasaan dalam pertikaian sesama suku Dayak yang dahulu kerapkali diselesaikan dengan tradisi mengayau atau memenggal kepala manusia. Dengan adanya perjanjian itu maka terjalinlah persatuan dan persaudaraan antar suku Dayak yang dulunya saling bermusuhan satu sama lain. Jika pada jaman dahulu betang menjadi tempat perjanjian, maka perbedaannya saat ini betang biasa dijadikan tempat untuk bermusyawarah mengambil keputusan.

Falsafah huma betang merupakan struktur kehidupan masyarakat Dayak sehari-hari. Banyak sekali keseharian dari masyarakat Suku Dayak yang memang mengacu pada nilai-nilai toleransi, kebersamaan, gotong royong, seperti yang ada pada falsafah huma betang itu sendiri. Kemudian yang menjadi penting di tengahtengah asumsi masyarakat menganggap kebudayaan sebatas daya tarik untuk destinasi pariwisata, sebatas mengindahkan prinsip adat yang dipegang nenek moyang atau leluhur, tanpa memelihara dan menginternalisasikan nilai-nilai budaya yang sarat akan nilai luhur filosofi kehidupan tersebut dalam kehidupan sehari-hari. Padahal menghormati leluhur merupakan poin penting dalam suku Dayak (T. Riwut, 2003), ini juga menjadi bagian dari pribadi suku Dayak yang 
dikatakan Wilson (2009) dengan istilah "Jite Keba" yaitu J - jujur, i - ikhlas, te tekun, K - konsekuen, e - ela, ba - balecak (ela balecak artinya jangan sombong)". Maka dari itu masyarakat suku Dayak sendiri perlu memperhatikan hal ini serta pemerintah setempat harus mampu bersinergi untuk memelihara cagar budaya secara fisik serta nilai-nilai yang ada dan terinternalisasi di dalamnya, sehingga manfaatnya dapat terasa bagi kehidupan bermasyarakat, berbangsa, dan bernegara. Filosofi kebudayaan Suku Dayak dalam huma betang memang berdampak pada setiap aspek kehidupan dari mulai tata cara adat sanksi hingga konsep kepemimpinan. Jika mengacu pada prinsip atau filosofi hidup masyarakat Suku Dayak dalam memilih pemimpin, terdapat beberapa kriteria sebagaimana dikemukakan Riwut (2015), yaitu:

Mamut Menteng. Gagah perkasa dalam sikap dan perbuatan, dalam artian seorang pemimpin, ia disegani bukan dari apa yang ia katakan, namun dari apa yang telah ia lakukan. Berani berbuat, berani bertanggung jawab. Dalam sikap dan perbuatan selalu adil. Apa yang diucapkan benar dan berguna. Nama baik bahkan jiwa raga dipertaruhkan demi keberpihakannya kepada warganya. Sikap mamut menteng yang dilengkapi dengan tekad isen mulang atau pantang menyerah telah mendarah daging dalam kehidupan orang Dayak;

Harati. Pandai, disamping pandai seorang pemimpin juga harus seorang yang cerdik dalam arti positif. Kecerdikannya mampu menjadikan dirinya sebagai seorang pemberi inspirasi bahkan sebagai seorang the greatest inspirator bagi warganya. Kemampuan dalam berkomunikasi dengan warganya, keakraban yang tidak dibuatbuat, menjadikan seorang pemimpin suku Dayak memiliki kepekaan yang tajam. Peka maksudnya sebelum peristiwa terjadi, ia telah terlebih dahulu menditeksi segala kemungkinan yang bakal terjadi di lingkungannya. Mampu membedakan antara yang benar dan yang salah;

Bakena. Tampan/cantik, menarik, dan bijaksana. Lebih luas maksudnya Inner beauty yaitu ketampanan/kecantikan yang terpancar dari dalam jiwa. Cahaya matanya memancarkan keadilan, perlindungan, rasa aman dan bakti. Dimanapun berada, ia akan selalu disenangi dan disegani. Semua ini secara otomatis akan muncul apabila segala tugas dan tanggung jawab dilaksanakan dengan ihklas tanpa pamrih;

Bahadat. Beradat, bukan hanya mengerti dan memahami hukum adat dan hukum pali dengan baik, namun nyata terlihat dalam tindakan sehari-hari. Ranying Hatalla atau Allah Yang Maha Kuasa turut serta mengawasi setiap tindakan yang dilakukan oleh para pemimpin, sehingga kendali diri pegang peranan dalam melaksanakan tugas dan tanggung jawabnya. Berani berlaku tidak adil konsekwensinya hukuman akhirat akan diterima setelah kematian terjadi;

Bakaji. Berilmu tinggi dalam bidang spiritual. Seorang pemimpin ia harus selalu berusaha untuk mencapai hening, serta membersihkan dan menyucikan jiwa, raga dengan rutin dan berkala. Saat hening adalah saat yang paling tepat untuk berdialog dengan diri sendiri, menata sikap untuk tetap kokoh berpegang pada tujuan agar 
tidak mudah terombang ambing. Kokoh kilau sanaman yang artinya sekokoh besi;

Barendeng. Mampu menjadi pendengar, yakni mendengarkan informasi juga keluhan warganya. Telinganya selalu terbuka bagi siapapun. Hal ini bukan berarti bahwa pemimpin suku Dayak hanya menghabiskan waktunya dengan menerima kunjungan warga untuk berkeluh kesah dan bersilaturahmi dengannya.

Pada hakikatnya filosofi kebudayaan menyangkut masalah nilai, yang mana nilai itu sendiri adalah sari dari kebudayaan yang dapat membimbing pada asas tujuan manusia termasuk di dalamnya menertibkan pola perilaku manusia melalui nilai-nilai yang ada pada filosofi kebudayaan. Nilai-nilai yang ada dalam falsafah huma betang merupakan wujud civic virtue yang mengarah atau cenderung pada pengembangan etika, moral, serta norma (Chuah, Hoffmann, Jones, \& Williams, 2009; Hill Jr, 2013; Stavrova, Schlösser, \& Fetchenhauer, 2013). Manfaat yang dirasakan oleh masyarakat Suku Dayak sendiri dari refleksi huma betang mungkin sudah dipandang biasa karena terinternalisasi dalam kehidupan sehari-hari dan tidak terasa karena sudah otomatis dilakukan dalam kurun waktu yang lama. Namun yang menjadi poin utama pada kajian ini adalah eksplorasi nilai-nilai moral kultural pada huma betang yang terkristalisasi dalam diri masyarakat Suku Dayak Ngaju, sehingga dikatakan sebagai sebuah identitas. Keberadaan dan implementasi nilai-nilai moral kultural pada huma betang yang dapat menjadi contoh sekaligus kontruksi kehidupan bermasyarakat, berbangsa, dan bernegara.

Masyarakat Dayak memandang huma betang sebagai sarana penting dalam menjalani kehidupan bermasyarakat khususnya di Kalimantan Tengah. Untuk itu perlu kiranya mengidentifikasi apa yang menjadi manfaat dari eksistensi dan implementasi huma betang sehingga dapat menjadi cerminan dalam kehidupan berbangsa dan bernegara. Nilai-nilai keadaban kewarganegaraan yang diimplementasikan pada keberadaan huma betang merupakan nilai-nilai luhur yang patut untuk dipelihara dan diwariskan guna pembangunan karakter mendatang dari aspek sosio-kultural. Pada hakikatnya nilai-nilai ini tidak seketika muncul pada diri masyarakat Suku Dayak, terutama penghuni maupun penduduk sekitar betang. Nilai-nilai ini tumbuh dalam pola hidup, adat istiadat, dan sistem kebudayaan yang dipegang oleh masyarakat Suku Dayak itu sendiri. Falsafah huma betang adalah makna kebudayaan yang menjadi suatu sistem norma dan nilai yang terorganisasi dan menjadi pegangan bagi masyarakat (Horton \& Hunt, 1984)

Peneliti memahami bahwa perilaku hanyalah salah satu unsur yang merepresentasikan suatu nilai. Oleh karenanya tidak cukup mengamati pola tingkah laku untuk memunculkan asumsi apakah suatu nilai masih dipelihara ataukah sudah mulai ditinggalkan. Sebab pada hakikatnya selain menjelema dalam bentuk perilaku, nilai ada yang terkristal menjadi prinsip yang terkadang tidak dapat muncul dalam satu dua kali perilaku. Peneliti mencoba memilah dari temuan penelitian yang didapat, nilai-nilai keadaban kewarganegaraan mana saja yang mapan namun mulai bergeser, nilai-nilai mana yang diadaptasi dan ditransformasikan dalam kehidupan suku Dayak di Kalimantan Tengah, serta nilai mana yang telah hilang. Adapun data mengenai nilai-nilai moral kultural tersebut 
diolah oleh peneliti dan dituangkan dalam skema sebagai berikut.

\section{Gambar 2 Klasifikasi Nilai-nilai dalam Falsafah Huma Betang}

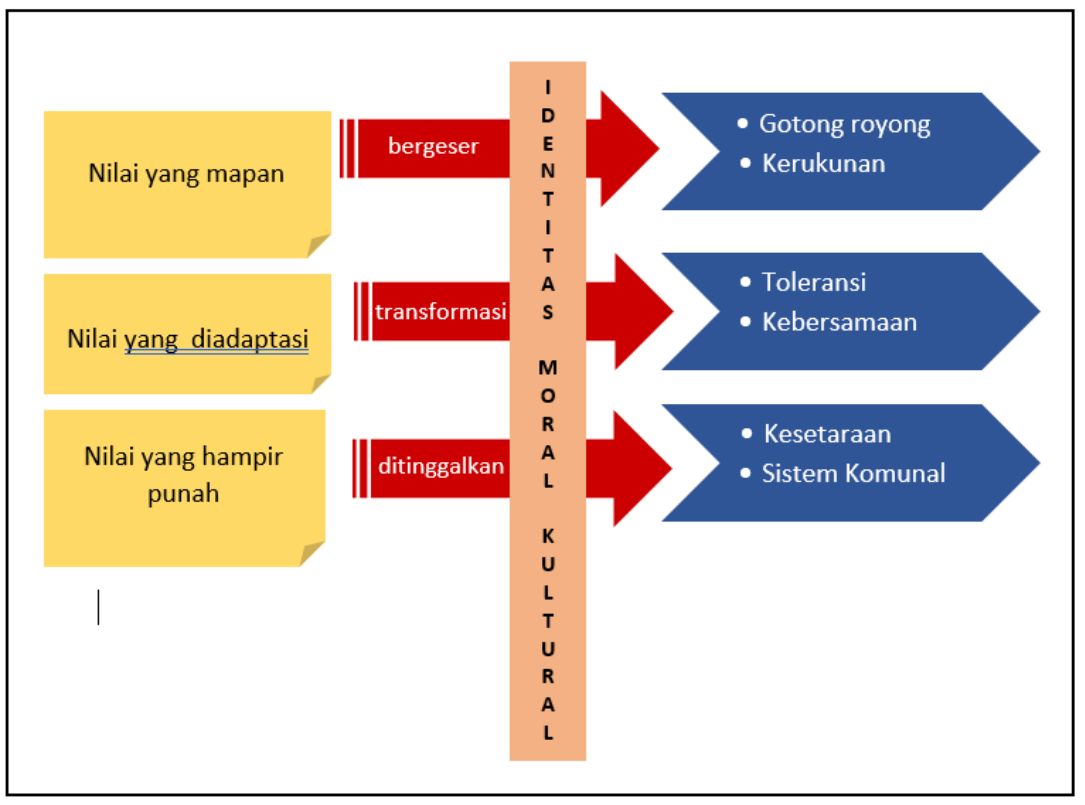

Sumber: Diolah Peneliti (2017)

\section{Gotong Royong}

Gotong royong mengalami pergeseran makna meski diklasifikasikan dalam nilai yang mapan dan terpelihara dengan baik. Hal ini berdasarakan pengakuan penghuni betang dan penduduk sekitar. Terdapat dua konteks pergeseran dalam nilai gotong royong: pertama, gotong royong yang dilakukan penghuni betang dan penduduk sekitar pada jaman dulu adalah saling membantu saat bertani, berladang, memasak bersama untuk upacara adat. Namun saat ini gotong royong dalam kegiatan bertani dan berladang sudah jarang dilakukan mengingat mata pencaharian penghuni dan penduduk sekitar betang yang mulai bervariasi. Meski sebagian besar mata pencaharian mereka adalah berladang dan menyadap karet, lebih sering dilakukan sendiri-sendiri karena rentang waktu yang dimiliki yang berbeda-beda. Berladang merupakan salah satu ciri-ciri penting dari suku Dayak disamping bertempat tinggal di pedalaman, dan mempraktekkan mengayau di masa silam (Coomans, 1987). Kedua, gotong royong jaman dulu dilakukan sebagai bentuk bantuan murni tanpa pamrih yang dilakukan tetangga dan sesama sanak saudara jika akan membuka lahan untuk berladang, bertani, atau menyadap karet. Jika hari ini membuka lahan di lokasi milik si A, maka besoknya berbondong-bondong beralih ke lokasi milik si B, begitu seterusnya dilakukan secara bergantian hingga pekerjaan selesai sama rata.

\section{Kerukunan}

Pergeseran nilai kerukunan yang sudah terjalin antara penghuni betang sejak jaman dahulu ditengarai karena banyak keluarga yang termasuk dalam silsilah betang memisahkan diri dan memilih tinggal di luar betang bahkan di luar desa dan di luar kota kabupaten. Hal ini mengakibatkan interaksi yang terjalin tidak sesering 
dan sedekat dahulu saat mereka berada dalam satu atap betang. Namun meski begitu nilai kerukunan masih dianggap sebagai nilai yang mapan dan terpelihara dengan baik oleh karena interaksi yang terjalin antara penghuni betang dan penduduk sekitar yang membaur dan jarang sekali terjadi perselisihan. Setiap sore berdasarkan hasil pengamatan peneliti, penghuni betang biasanya keluar rumah untuk duduk-duduk santai di tangga, kemudian tetangga lain menghampiri dan satu sama lainnya mulai berbincang hangat hingga menjelang petang. Waktu kebersamaan mereka hanya bisa diamati saat sore menjelang malam hari dikarenakan pagi hari sebelum matahari terbit penghuni maupun penduduk sekitar betang sudah keluar rumah untuk bekerja dengan bermacam tujuan yang berbeda.

\section{Toleransi}

Toleransi merupakan nilai yang mapan dan terpelihara dalam kehidupan masyarakat Dayak dan merupakan refleksi dari pola kehidupan di huma betang yang terdiri agama, suku, sifat, karakter, yang berbeda beda. Toleransi ini telah pula menjadi iklim interaksi yang tidak terpisahkan dari masyarakat Kalimantan Tengah. Toleransi menjadi kerangka yang kuat dalam kehidupan bermasyarakat terutama masyarakat Indonesia, khususnya Kalimantan Tengah yang heterogen. Saat ini nilai toleransi yang menjadi inti dari falsafah huma betang telah bertransformasi dalam kondisi gereja dan masjid dengan lokasi yang berdampingan. Bangunan gereja dan masjid yang berdekatan ini banyak ditemui di jalan-jalan di Kalimantan Tengah.

\section{Kebersamaan}

Kebersamaan merupakan filosofi hidup Suku Dayak yang terinternalisasi dalam prinsip hidup belom bahadat. Disamping itu nilai kebersamaan dapat searah dalam kontek Pendidikan Kewarganegaraan jika dikategorikan dalam hal-hal yang positif dalam artian bermanfaat baik. Dewasa ini nilai kebersamaan baik secara langsung maupun tidak langsung, secara sadar maupun tidak sadar, telah terimplementasi dalam kehidupan sehari-hari termasuk halnya kehidupan masyarakat Suku Dayak. Melalui nilai kebersamaan ini tercermin pula falsafah huma betang yang mengedepankan musyawarah untuk mufakat, sebab dengan kebersamaan yang terjalin, komunikasi bisa berjalan dengan baik.

\section{Kesetaraan}

Huma betang dalam falsafahnya telah mampu mengikat berbagai perbedaan menjadi suatu kesamaan dan persatuan antar Suku Dayak. Hal ini secara eksplisit diungkapkan dalam inti budaya dan filosofi huma betang "berdiri sama tinggi duduk sama rendah dimana kaki dipijak disitu langit dijunjung". Kesetaraan sesama manusia kerapkali ditafsirkan sebagai nilai universalitas yang mengacu pada kesamaan derajat manusia. Pada jaman dahulu saat kesetaraan gender masih belum menjadi hal lumrah, nilai kesetaraan menjadi penting. Antara laki-laki dan perempuan awalnya tidak memiliki derajat yang sama seperti sekarang. Namun setelah kesetaraan gender dan paham feminism merebak, nilai kesetaraan beralih menjadi kesetaraan yang mengisi social gap. Pada falsafah huma betang, maksud daripada nilai kesetaraan yang sudah mulai punah ditandai dengan pola pikir penghuni yang mulai maju, kesetaraan telah mereka pahami sebagai pertemuan 
antara hak dan kewajiban yang seimbang antar individu. Maka dari itu nilai tersebut sudah melekat dan dipandang sebagai penghalang jika terus dibawa-bawa. Nilai kesetaraan ini akan berdampak pula pada kapasitas dan kompetensi seseorang yang tidak mengalami kemajuan karena orang yang dimaksud dalam huma betang ini cenderung memiliki prinsip kesamaan dari keseteraan itu sendiri, tidak ada perubahan yang dilakukan.

\section{Sistem Komunal}

Komunalisme merupakan ciri khas masyarakat Dayak dalam berbagai aktivitas seperti misalnya berburu pada jaman dahulu. Hal ini dibenarkan Laksono (2006) yang menerangkan bahwa "nilai yang menonjol dalam kehidupan di rumah betang adalah nilai kebersamaan (komunalisme) di antara para warga yang menghuninya, terlepas dari perbedaan-perbedaan yang mereka miliki". Hingga kini sistem komunal yang melekat pada nilai gotong royong dan kebersamaan menjadi pengikat interaksi sosial masyarakat Suku Dayak di Kalimantan Tengah. Realitas yang terjadi di lapangan menggambarkan sistem komunal yang sudah mulai punah dan ditinggalkan oleh penghuni betang dalam beberapa konteks. Pola pikir penghuni betang yang cukup maju, ditambah interaksi dengan wisatawan domestik dan mancanegara, serta iptek yang berkembang pesat membuat nilai komunal ini dianggap menghambat seseorang dalam berinovasi dan berkreasi, termasuk halnya ketika salah satu keluarga betang yang ingin tinggal di luar, dan mengenyam pendidikan di luar betang.

\section{SIMPULAN}

Falsafah huma betang Suku Dayak Ngaju merupakan salah satu kearifan lokal Kalimantan Tengah yang masih terpelihara higga saat ini. Huma betang sebagai identitas moral kultural Suku Dayak merupakan rumah adat asli Suku Dayak yang didirikan oleh nenek moyang pada jaman dahulu. Huma betang lebih dari sekedar tempat tinggal bagi masyarakat Suku Dayak, huma betang mencerminkan filosofi hidup Suku Dayak atau dapat dikatakan jantung dari struktur kehidupan orang Dayak. Hal ini dikarenakan huma betang mengandung unsur-unsur berupa nilai, moral, hukum adat, kebiasaan, yang sudah dianggap sebagai pandangan hidup bagi masyarakat Suku Dayak.

Nilai-nilai yang tercermin dalam falsafah huma betang merupakan identitas kultural Suku Dayak Ngaju Kalimantan Tengah. Adapun nilai-nilai tersebut ialah gotong royong, kebersamaan, toleransi, rukun, dan hidup berdampingan. Nilai-nilai ini juga mirip dengan filosofi hidup suku Dayak, yaitu belom bahadat, handep, serta hapungkal lingu nalatai hapangjan. Nilai-nilai inilah yang sepatutnya dipelihara sebagai kearifan lokal di Kalimantan Tengah. Meskipun huma betang merupakan unsur budaya dalam bentuk fisik, namun falsafah yang tercermin di dalamnya telah hidup sejak huma betang itu didirikan dan melekat dalam kebiasaan sehari-hari Suku Dayak.

Identitas kultural yang terrefleksi dari keberadaan huma betang, yaitu 1) huma betang sebagai refleksi kehidupan masyarakat yang toleran (togetherness in diversity); 2) huma betang sebagai asal mula tumbuhnya rasa persatuan dan kebersamaan antar suku Dayak setelah kesepakatan damai Tumbang Anoi; 3) huma betang sebagai 
replika sistem komunal yang dianut masyarakat Suku Dayak; 4) huma betang mengandung pola kosmologi yang mencerminkan keseimbangan sebuah nilai; 5) huma betang sebagai cerminan kehidupan demokratis dan egaliter; 6) huma betang melalui pola kehidupan di dalamnya melahirkan konsep kepemimpinan Suku Dayak seperti mamut menteng, isen mulang, dsb; huma betang merepresentasikan prinsip kolektif; 7) huma betang sebagai model ideal sistem masyarakat yang pluralis.

\section{REFERENSI}

Abdillah, H. (2011). Indonesia Laboratorium bagi Keragaman Budaya. Retrieved October 7, 2016, from http://www.kemendagri.go.id/news/2011/11/02/indonesia-laboratoriumbagi-keragaman-budaya

Ade, V., \& Affandi, I. (2016). Implementasi nilai-nilai kearifan lokal dalam mengembangkan keterampilan kewarganegaraan (Studi deskriptif analitik pada masyarakat Talang Mamak Kec. Rakit Kulim, Kab. Indragiri Hulu Provinsi Riau). Jurnal Pendidikan Ilmu Sosial, 25(1), 77-91.

Badan Pusat Statistik. (2018). Kewarganegaraan, Suku Bangsa, Agama, dan Bahasa Sehari-hari Penduduk Indonesia. Jakarta: BPS.

Chuah, S.-H., Hoffmann, R., Jones, M., \& Williams, G. (2009). An economic anatomy of culture: Attitudes and behaviour in inter-and intra-national ultimatum game experiments. Journal of Economic Psychology, 30(5), 732-744.

Coomans, M. (1987). Manusia Daya: dahulu, sekarang, masa depan. Jakarta: Gramedia. Depdiknas. (2018). Kamus Besar Bahasa Indonesia Pusat Bahasa. Jakarta: Gramedia.

Eviyanti. (2010). Taman Budaya Borneo Tengah. Retrieved from ejournal.uajy.ac.id/2374/2/1TA12077.pdf

Fanani, A. (2009). Kamus Istilah Populer. Yogyakarta: Penerbit Mitra Pelajar.

Haviland, W. A. (1985). Antropologi, Edisi Keempat, Jilid 1, Terjemahan RG Soekadijo. Jakarta: Erlangga.

Hill Jr, T. E. (2013). Two conceptions of virtue. Theory and Research in Education, 11(2), 167-186.

Horton, P. N., \& Hunt, C. L. (1984). Sociology (5th ed.). Jakarta: Erlangga.

Koentjaraningrat, K. J. (1993). Kebudayaan, Mentalitas dan Pembangunan. Jakarta: Gramedia Pustaka Utama.

Laksono. (2006). Pergulatan Identitas Dayak dan Indonesia: Belajar dari Tjilik Riwut. Yogyakarta: Penerbit Galang Press.

Langub, J. (2012). The Human Heart of Borneo. Kuala Lumpur: Heart of Borneo Elder\&WWF Trustee.

Lickona, T. (2013). Character Matters: Persoalan Karakter. Jakarta: Bumi Aksara.

Nainggolan, L. L. (2015). (2016). Generasi Muda dan Kebudayaan Nasional. Retrieved from http://www.pontianakpost.com/generasi-muda-dankebudayaan-nasional

Neuman, L. (2003). Social Research Method (Qualitative and Quantitative Approach (5th ed.). Boston: Allyn and Bacon.

Nurhadi. (2006). Cultural Studies: Teori dan Praktik. Yogyakarta: Kreasi Wacana. 
Pemerintah Republik Indonesi. (2010). Desain Induk Pembangunan Karakter Bangsa Tahun 2010-2025. Jakarta: Departemen Pendidikan Indonesia.

Pemerintah Republik Indonesia. (2010). Desain Induk Pembangunan Karakter Bangsa Tahun 2010-2025. Jakarta: Pemerintah RI. Jakarta: Pemerintah Republik Indonesia.

Raco, J. R. (2010). Metode Penelitian Kualitatif. Jenis, Karakteristik, dan Keunggulannya. Jakarta: Gramedia.

Restyanto, Y. (2012). Ukuran Elemen Arsitektur Betang Toyoi. Jurnal Perspektif Arsitektur, 7(2), 9-23.

Riwut, N. (2015). Konsep Kepemimpinan Suku Dayak Khususnya di Daerah Kalimantan Tengah. Yogyakarta: NR Publishing.

Riwut, T. (2003). Maneser panatau tatu hiang: menyelami kekayaan leluhur. Palangkaraya: Pustaka Lima.

Sangalang, I., Titi, E., \& Darjosanjoto, S. (2011). The DAYAK adaptation in kampong of Kahayan riverside. Journal of Basic and Applied Scientific Research, 1(4), 283289.

Sardjiyo. (2011). Kajian pendidikan nilai sebagai dukungan akademik terhadap Pendidikan Karakter (Studi kasus di UPI Bandung). Universitas Pendidikan indonesia.

Setiadi, E. M. (2006). Ilmu Sosial dan Budaya Dasar. Jakarta: Kencana Prenada Media Group.

Soekanto, S. (2014). Sosiologi Suatu Pengantar. Jakarta: RajaGrafindo Persada.

Stavrova, O., Schlösser, T., \& Fetchenhauer, D. (2013). Are virtuous people happy all around the world? Civic virtue, antisocial punishment, and subjective wellbeing across cultures. Personality and Social Psychology Bulletin, 39(7), 927-942.

Sukarwo, W. (2017). Krisis Identitas Budaya: Studi Poskolonial pada Produk Desain Kontemporer. Jurnal Desain, 4(03), 311-324.

Tugiman, H. (2012). Etika Rambu-Rambu Kehidupan. Yogyakarta: Kanisius.

William, C. (2017). Merawat Reputasi Bangsa. Kompas.

Wilson, W. (2009). Makna Upacara Nyaki Tihi Adat Dayak Ngaju di Desa Samba Danum Katingan, Kalimantan Tengah. Kontekstualita: Jurnal Penelitian Sosial Keagamaan, 24(2).

Zainuddin, H. (2012). Huma Betang Simbol Kerukunan Warga. Retrieved from http:/ / regional.kompas.com/read/2012/08/04/22291748/quothuma.betang quot.simbol.kerukunan.warga 